\title{
Evaluasi Faktor Keamanan Geometri Lereng Tanggul Sidoarjo di Daerah Tanggul Utara Daerah Lumpur Sidoarjo
}

\author{
Roni Alberto Pakpahan ${ }^{1}$, Najib Najib ${ }^{1}$, Nurakhmi Qadaryati ${ }^{*}$ \\ Departemen Teknik Geologi, Fakultas Teknik, Universitas Diponegoro \\ Jl. Prof. Soedharto, SH., Tembalang, Semarang
}

\begin{abstract}
Abstrak
Pada bencana Lumpur Sidoarjo, pembangunan tanggul merupakan salah satu penanggulangan untuk membatasi dampak terjadinya Lumpur Sidoarjo. Tanggul bagian utara Lumpur Sidoarjo merupakan salah satu segmen yang pernah mengalami keruntuhan. Sebenarnya risiko keruntuhan tanggul dapat diminimalkan dengan mengevaluasi faktor keamanan (FK) dari segmen tanggul yang rutin. Penelitian ini bertujuan untuk mengevaluasi FK di tanggul utara dan menentukan rekomendasi peningkatan FK. Metode penelitian mencakup analisis evaluasi stabilitas lereng dengan menggunakan parameter geometri lereng tanggul dari lapangan dan dari hasil uji laboratorium. Daerah penelitian tersusun dari satuan tanah asli berupa endapan aluvium berukuran pasir-lempung dan satuan tanah urugan berupa material pasir-kerakal. Pada kondisi tampungan normal dan tanpa gempa, FK di bagian hilir tanggul P74 dan P75 tergolong aman (1,572 dan 1,580). Tanggul P79 tergolong rentan karena memiliki FK 0,840 dengan kondisi tampungan normal dan tanpa gempa. Rekomendasi untuk peningkatan nilai FK adalah pemadatan tanah, membuat kawat pada bagian hulu, pelandaian lereng tubuh tanggul dan penutupan rekahan, serta pembuataan drainase pada hilir tanggul.
\end{abstract}

Kata kunci: Faktor keamanan; kestabilan lereng; Lumpur Sidoarjo; tanggul.

\begin{abstract}
In the case of Lumpur Sidoarjo, the embankment construction is one of the procedure to control the impact of the Sidoarjo Mudflow. The northern part of Lumpur Sidoarjo embankment is one of the segments that has experienced a collapse. The risk of collapse can be reduced by conducting an annual safety factor (SF) evaluation on the embankment segment. This study aims to evaluate the safety of embankments for monitoring purposes. The research method applies the Bishop's method to analyze the slope stability using geometry parameters of embankment slopes from the field and from laboratory test results. The study area is composed of original soil unit (alluvium deposit of sand-clay) and barrow unit (consist of sand-gravel sized sediment). Under normal storage condition and no earthquake, SF in the downstream of P74 and P75 embankments is relatively safe (1,572 and 1,580). $P 79$ embankment is classified as vulnerable because it has FK 0.840 in normal storage condition and no earthquake. Recommendations for enhancing FK values are: soil compaction, making wires upstream, sloping embankment slopes and fracture closure, and drainage drainage at the embankment downstream.
\end{abstract}

Keywords: Safety factor; slope stability; Lumpur Sidoarjo; embankment.

\section{PENDAHULUAN}

Lumpur Sidoarjo merupakan suatu aliran panas, air, disertai dengan lumpur yang keluar dari perut bumi di Kabupaten Sidoarjo. Lumpur Sidoarjo terjadi pada 29 Mei 2006 dan masih erupsi hingga saat ini, dalam sehari intensitas lumpur yang keluar dapat mencapai $5.000 \mathrm{~m}^{3}$ perhari. Besarnya intensitas lumpur mengharuskan adanya suatu penanggulangan.

Tanggul penahan Lumpur Sidoarjo merupakan salah satu solusi untuk menanggulangi perluasan dari daerah yang terdampak Lumpur Sidoarjo. Fungsinya yang sangat penting untuk menahan dampak dari bencana Lumpur Sidoarjo, pembangunan kontruksi tanggul tentunya memiliki peranan yang sangat penting. Dalam banyak kasus potensi runtuhnya tanggul dapat mengakibatkan suatu bencana baru berupa kerusakan properti atau bahkan suatu korban jiwa. Pembangunan kontruksi tanggul harus diikuti dengan pemeliharaan tanggul (Robbins, 1946).

Ada beberapa hal yang sangat penting yang dapat dilakukan dalam monitoring tanggul. Erosi

*) Korespondensi : nurakhmi@live.undip.ac.id 
pada tanggul merupakan hal yang perlu dilakukan monitoring, dimana material tanggul penahan Lumpur Sidoarjo yang terbuat dari tanah mengalami suatu penggerusan pada bagian dalam. Akibat dari hal tersebut adanya rembesan yang berdampak pada suatu perbesaran kebocoran dan tekanan air yang tinggi dalam tubuh tanggul. Apabila proses erosi terus dibiarkan maka akan mengakibatkan runtuhnya tanggul.

Sejak tahun 2006 tanggul penahan Lumpur Sidoarjo belum dilakukan suatu monitoring intensif dari waktu ke waktu yang mengakibatkan Salah satu longsor pernah ada terjadi pada bagian sisi utara tanggul di P67 (Mazzini dkk., 2012), serta timur laut pada titik P80-81 (Husein dkk., 2014). Kedepannya penelitian ini diharapkan dapat digunakan sebagai acuan penentuan kondisi stabilitas tanggul dan zona lemah pada tiap bagian tanggul sehingga proses perawatan atau perbaikan tanggul sesuai dengan sasaran perencanaan.

\section{METODOLOGI}

Proses penelitian dibagi menjadi beberapa tahapan yaitu studi pustaka dan persiapan, observasi geologi lapangan, pengambilan sampel air, analisis geokimia fluida, analisis kestabilan lereng dengan menggunakan bantuan software geoslope, berdasarkan data geometri lereng tanggul yang diperoleh dari lapangan.

\section{Metode Analisis Kestabilan lereng}

Analisis kestabilan lereng dengan software geoslope 2012 dengan menggunakan data pengukuran geometri lereng tanggul di lapangan dan juga parameter uji laboratorium yaitu bobot isi, kohesi, dan sudut geser dalam. Kemudian diinput kedalam software untuk dilakukan analisis dari hasil tersebut kemudian menghasilkan nilai dari faktor keamanan. Secara matematis, kestabilan suatu lereng dapat dinyatakan dalam suatu persamaan dalam bentuk Faktor Keamanan (FK) dalam persamaan (1).

$$
F K=\frac{\text { Gaya Penahan }}{\begin{array}{c}
\text { Gaya Penggerak } \\
\text { Dengan: }
\end{array}}
$$

FK > 1: Lereng dianggap stabil.

$\mathrm{FK}=1$ : Lereng dalam keadaan setimbang tetapi akan segera longsor jika mendapatkan sedikit gangguan.

FK $<1$ : Lereng dianggap tidak stabil.
Apabila nilai faktor keamanan memiliki nilai yang tinggi, maka tidak diperlukannya rekomendasi penanganan. Apabila nilai faktor keamanan memiliki nilai rendah, kemudian dilakukan re-desain geometri lereng tanggul dan juga peninggian tanggul dengan faktor keamanan yang telah ditentukan aman berdasarkan Badan Standarisasi Nasional (BSN). Dalam analisis kestabilan lereng menggunakan metode Bishop

\section{Metode Bishop}

Metode Bishop adalah Metode yang diperkenalkan oleh A.W. Bishop menggunakan cara potongan dimana gaya-gaya yang bekerja pada tiap potongan ditunjukkan seperti pada Gambar 1. Metode Bishop dipakai untuk menganalisis permukaan gelincir (slip surface) yang berbentuk lingkaran. Dalam metode ini diasumsikan bahwa gaya-gaya normal total berada/bekerja dipusat alas potongan dan bisa ditentukan dengan menguraikan gaya-gaya pada potongan secara vertikal atau normal.

Persyaratan keseimbangan dipakai pada potongan-potongan yang membentuk lereng tersebut. Metode Bishop menganggap bahwa gaya-gaya yang bekerja pada irisan mempunyai resultan nol pada arah vertikal Bishop, 1955). Untuk lereng yang dibagi menjadi $\mathrm{n}$ buah slice (irisan). Gaya-gaya geser yang bekerja pada $\mathrm{n}$ irisan diasumsikan mewakili seluruh bagian yang sama dari kuat geser batuan/ tanah dimana gaya-gaya geser ini bekerja diuraikan dalam Tabel 1 .

Secara umum metode simplified bishop memperhitungkan komponen gaya horizontal dan vertikal dengan memperhatikan keseimbangan momen dari masing-masing potongan. Metode ini sangat cocok digunakan untuk pencarian secara otomatis bidang runtuh kritis yang berbentuk busur lingkaran. Metode ini juga sangat cocok untuk untuk mencari faktor kemanan minimum.

Tabel 1 Persamaan yang diketahui pada metode Bishop vertikal (Bishop, 1955 dalam Rajagukguk dkk, 2014).

\begin{tabular}{cc}
\hline Persamaan yang ada & Jumlah \\
\hline Keseimbangan Normal & $\mathrm{n}$ \\
Keseimbangan Tangensial & $\mathrm{n}$ \\
Kesimbangan Momen & $\mathrm{n}$ \\
\hline Total & $3 \mathrm{n}$ \\
\hline
\end{tabular}




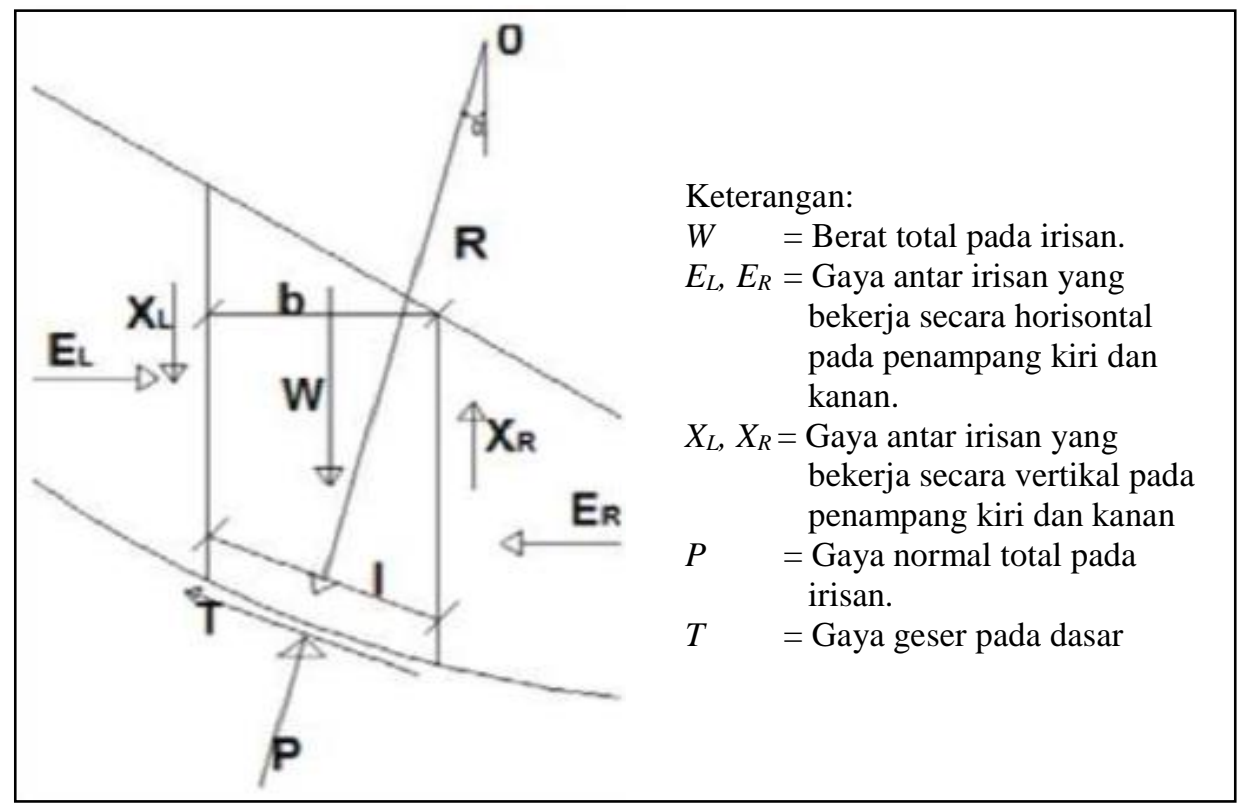

Gambar 1. Gaya-gaya yang bekerja pada suatu potongan (Bishop, 1955).

\section{HASIL PENELITIAN}

\section{Geologi Teknik Daerah Penelitian}

Peta geologi teknik bertujuan informasi persebaran jenis tanah dan batuan serta sifat fisik dan mekanik tanah atau batuan. Sifat keteknikan tanah diperlukan untuk analisis kestabilan lereng antara lain berat isi, kohesi, dan sudut geser dalam. Parameter tersebut diperoleh dari pengujian laboratorium. Untuk nilai kohesi dan sudut geser dan berat isi kemudian dijadikan salah satu parameter untuk analisis kestabilan lereng.

Berdasarkan hasil pemetaan dan uji laboratorium, kondisi geologi teknik dibagi menjadi beberapa satuan yaitu satuan tanah urugan, satuan tanah asli berupa lempung, dan satuan lumpur lapindo. Distribusi satuan dapat dilihat pada Gambar 2.

\section{Satuan Tanah Urugan}

Daerah Satuan Tanah Urugan ditunjukkan dengan warna coklat pada peta geologi teknik. Penyebarannya memiliki distribusi sekitar 15\%. Pada umumnya, penyebaran tanah urugan tersebar pada lingkungan penduduk.

Satuan tanah urugan adalah sumber tanah bukan dari tanah asli pada daerah tersebut kenampakan dilapangan daerah tanah memiliki warna coklat kemerahan dengan ukuran butir pasir hingga kerikil.
2. Satuan Tanah Asli (Lempung dan Pasir)

Persebaran satuan tanah asli mencakup $45 \%$ bagian dari daerah penelitian. Satuan ini dijumpai pada daerah bebas pemukiman, yaitu di sekitar tanggul. Sampel yang digunakan untuk uji laboratorium pada satuan ini diperoleh dari BH 4. Satuan lempung dan pasir memiliki berat volume tanah 17,45 $\mathrm{KN} / \mathrm{m}^{3}$, dengan komposisi lempung sekitar $89,63 \%$ dan pasir $10,37 \%$. Sifat mekanik berupa nilai kohesi $39 \mathrm{kN} / \mathrm{m}^{2}$, sudut geser dalam $0 \phi^{0}$.

Berdasarkan material sampel lumpur untuk uji laboratorium pada satuan ini memiliki komposisi lempung/lanau 93,38\% dan pasir $4,72 \%$ dan kerikil 1,90\%. Nilai kadar air lumpur lapindo sekitar 60,52\%. Sifat mekanik berupa nilai kohesi $9,46 \mathrm{kN} / \mathrm{m}^{2}$, sudut geser dalam $28,53 \phi^{0}$.

3. Satuan Lumpur Lapindo

Daerah lumpur lapindo pada daerah penelitian mencakup sekitar $40 \%$ daerah penelitian ditandai dengan warna abu-abu muda pada peta geologi teknik. Material lumpur memiliki warna relatif abu-abu.

\section{Analisis Gempa}

Salah satu faktor yang mempengaruhi kestabilan lereng salah satunya ialah tingkat kegempaan pada daerah tersebut. Kegempaan pada suatu daerah pada umumnya akan menghasilkan suatu rekahan pada suatu permukaan ataupun di bawah permukaan. 


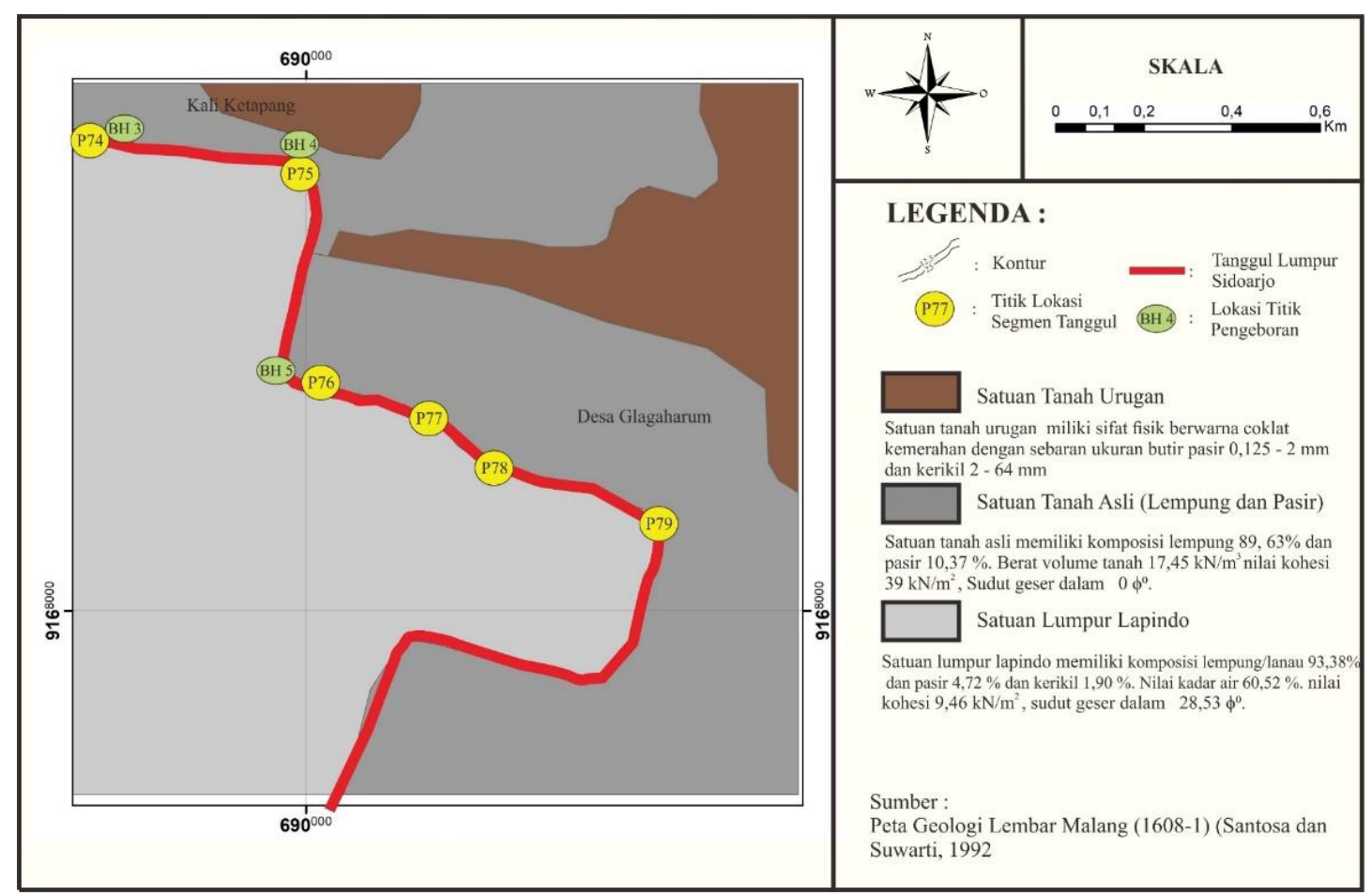

Gambar 2. Peta Geologi Teknik Daerah Lumpur Sidoarjo Tanggul Utara.

Tabel 2. Nilai koefisien gempa.

\begin{tabular}{cccc}
\hline \multicolumn{2}{c}{ Horizontal } & \multicolumn{2}{c}{ Vertikal } \\
$\mathrm{K}_{\mathrm{O}}$ & & \multicolumn{2}{c}{$\mathrm{K}$} \\
\hline OBE & MDE & OBE & MDE \\
0,08 & 0,22 & 0,112 & 0,308 \\
\hline
\end{tabular}

Tabel 1.3 Rekapitulasi analisis kestabilan lereng P74.

\begin{tabular}{lrrrrrr}
\hline \multirow{2}{*}{ Kondisi Tampungan } & \multicolumn{2}{c}{ Tanpa Gempa } & \multicolumn{2}{c}{ Gempa OBE } & \multicolumn{2}{c}{ Gempa MDE } \\
\cline { 2 - 7 } & \multicolumn{1}{c}{ Hulu } & \multicolumn{1}{c}{ Hilir } & \multicolumn{1}{c}{ Hulu } & \multicolumn{1}{c}{ Hilir } & \multicolumn{1}{c}{ Hulu } & \multicolumn{1}{c}{ Hilir } \\
\hline Kosong & 1,375 & 1,728 & 1,217 & 1,466 & 1,045 & 1,202 \\
Normal & 1,435 & 1,572 & 1,392 & 1,337 & 0,979 & 1,11 \\
Surut Tiba - Tiba & 1,29 & 1,7 & 1,136 & 1,466 & 0,976 & 1,202 \\
\hline
\end{tabular}

Tabel 1.4 Rekapitulasi analisis kestabilan lereng P75.

\begin{tabular}{lcrrrrr}
\hline \multirow{2}{*}{ Kondisi Tampungan } & \multicolumn{2}{c}{ Tanpa Gempa } & \multicolumn{2}{c}{ Gempa OBE } & \multicolumn{2}{c}{ Gempa MDE } \\
\cline { 2 - 7 } & \multicolumn{1}{c}{ Hulu } & \multicolumn{1}{c}{ Hilir } & \multicolumn{1}{c}{ Hulu } & \multicolumn{1}{c}{ Hilir } & \multicolumn{1}{c}{ Hulu } & \multicolumn{1}{c}{ Hilir } \\
\hline Kosong & 1,331 & 1,7 & 1,179 & 1,445 & 1,015 & 1,183 \\
Normal & 1,315 & 1,58 & 1,119 & 1,341 & 0,935 & 1,081 \\
Surut Tiba - Tiba & 1,257 & 1,714 & 1,112 & 1,445 & 0,959 & 1,16 \\
\hline
\end{tabular}

Tabel 1.5 Rekapitulasi analisis kestabilan lereng P79.

\begin{tabular}{|c|c|c|c|c|c|c|}
\hline \multirow{2}{*}{ Kondisi Tampungan } & \multicolumn{2}{|c|}{ Tanpa Gempa } & \multicolumn{2}{|c|}{ Gempa OBE } & \multicolumn{2}{|c|}{ Gempa MDE } \\
\hline & Hulu & Hilir & Hulu & Hilir & Hulu & Hilir \\
\hline Kosong & 0,792 & 1,061 & 0,685 & 0,957 & 0,566 & 0,848 \\
\hline Normal & 0,722 & 0,84 & 0,636 & 0,781 & 0,508 & 0,731 \\
\hline Surut Tiba - Tiba & 0,7 & 1,012 & 0,661 & 0,9 & 0,548 & 0,837 \\
\hline
\end{tabular}


Hal tersebut akan sangat mempengaruhi kestabilan lereng, terlebih besaran rambatan gelombang dari suatu getaran pada saat gempa yang ada pada suatu lereng. Dalam analisis gempa dilakukan berdasarkan sejarah kegempaan dari suatu daerah. Adapun sejarah kegempaan ditinjau dari jarak terdekat hingga jarak terjauh dari waktu pembanggunan tanggul. Pembagian tersebut dikenal dengan Operating
Basis Earthquake (OBE) dan Maximum Design Earthquake (MDE).

Berdasarkan hasil dari perhitungan diperoleh nilai koefisien gempa antara lain diuraikan dalam Tabel 2. Nilai tersebut menjadi salah satu parameter dalam analisis faktor keamanan untuk menentukan nilai faktor keamanan stabilitas tanggul.

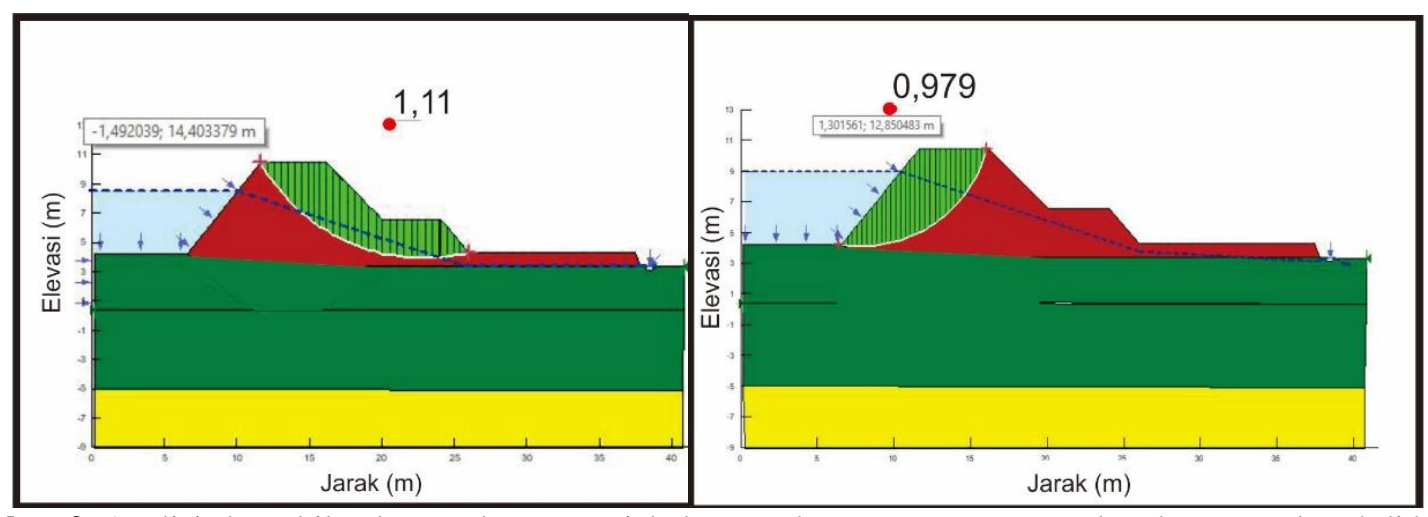

Gambar 3. Analisis kestabilan lereng dengan variabel MDE dan tampungan normal pada Tanggul P74 di bagian hilir (kiri) dan bagian hulu (kanan). Bagian hulu memiliki FK yang lebih rendah, yaitu 0,979.

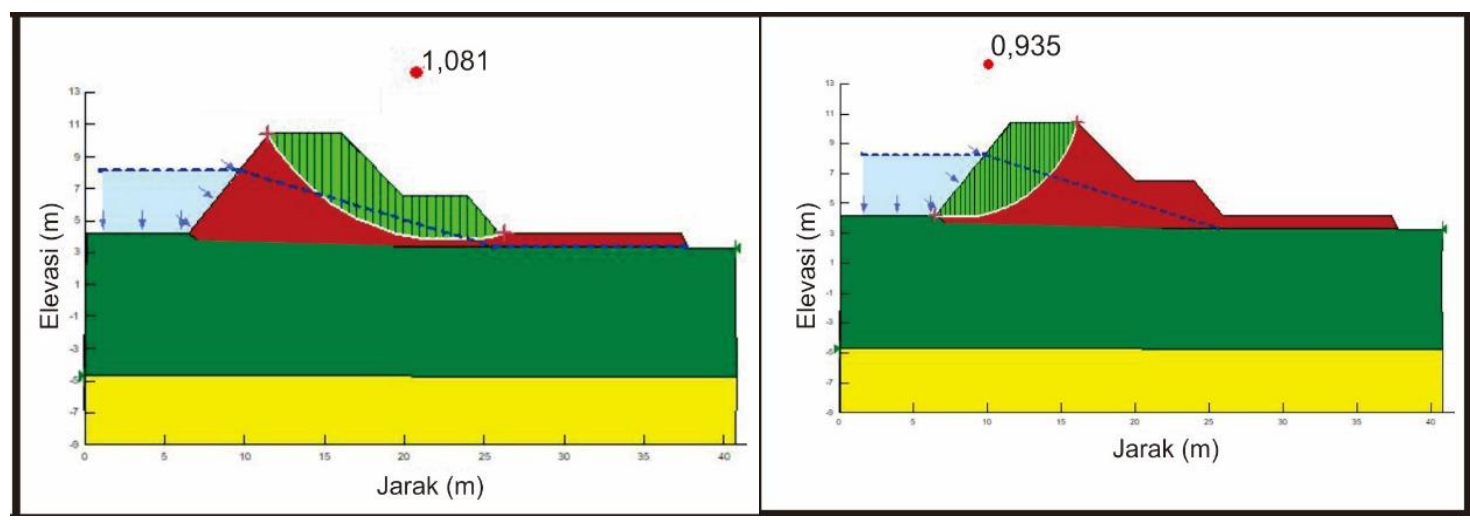

Gambar 4. Analisis kestabilan lereng dengan variabel MDE dan tampungan normal pada Tanggul P75 di bagian hilir (kiri) dan bagian hulu (kanan). Tanggul P75 memiliki FK yang lebih rendah di bagian hulu, yaitu 0,935.

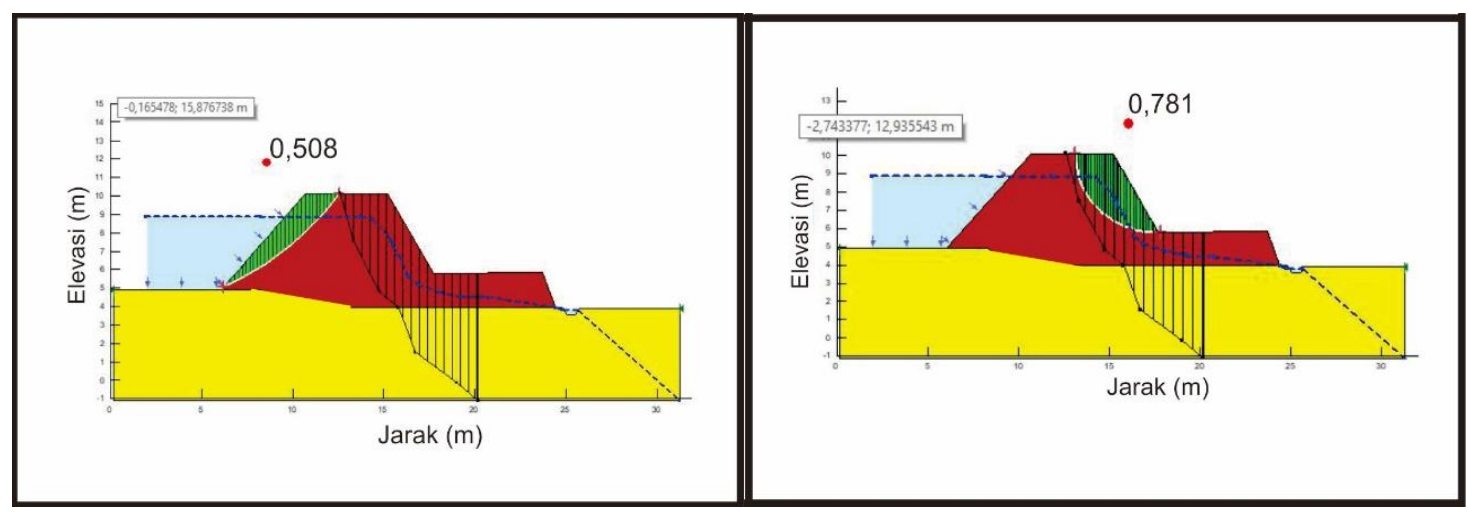

Gambar 5. Analisis kestabilan lereng dengan variabel MDE dan tampungan normal pada Tanggul P79 di bagian hilir (kiri) dan bagian hulu (kanan). Tanggul P79 memiliki FK yang paling rendah di daerah penelitian, FK hilir 0,781 dan FK hulu 0,508. 


\section{Analisis Kestabilan Lereng}

Kestabilan lereng suatu tanggul dapat juga berubah ketika ada perubahan volume massa yang ditampung. Oleh karena itu, pada masingmasing bagian hulu dan hilir dari tanggul P74, P75, dan P79 dilakukan analisis kestabilan lereng yang dibuat dalam tiga kondisi tampungan, yaitu pada saat tampungan kosong, terisi, dan surut secara tiba-tiba. Rekapitulasi analisis kestabilan lereng tanggul disajikan dalam Tabel 3-5.

\section{PEMBAHASAN}

\section{Kestabilan Lereng Tanggul P74}

Dari hasil analisis kestabilan tanggul P74 dengan kondisi tampungan saat normal maupun saat gempa OBE dalam kondisi relatif aman. Pada kondisi gempa MDE dengan asumsi pada saat kondisi tanggul mengalami surut tiba - tiba dan kondisi air normal. Tingkat dari kestabilan lereng tanggul relatif lebih rendah di bandingkan dengan kondisi lainnya dengan nilai FK 0,976 dan FK 0,979. Hal ini tentunya penanganan berupa rekomendasi untuk menjadikan tanggul relatif lebih stabil. Untuk menghindari terjadinya suatu kelongsoran. Walaupun untuk kondisi permukaan tanggul belum adanya suatu rekahan, namun perlu adanya pemantauan rutin pada daerah tanggul P74.

Berdasarkan hasil analisis dapat di simpulkan bahwa kondisi pada daerah hilir tanggul memiliki tingkat keamaanan lebih tinggi dibandingkan dengan sisi hulu tanggul.

\section{Kestabilan Lereng Tanggul Tanggul P75}

Berdasarkan hasil analisis pada kondisi MDE, sisi hulu Tanggul P75 memiliki nilai kestabilan lereng terendah yaitu 0,935 dengan tampungan normal. Namun, hal tersebut masih dapat di terima karena nilai kestabilan lereng daerah tersebut masih mendekati angka satu. Tapi untuk menghidari terjadinya suatu kelongsoran karena nilainya yang berada mendekati kata aman maka harus dilakukan penanggulangan dan hal menjadi suatu rekomendasi tanggul yang perlu adanya pemantauan rutin. Secara umum, kondisi Tanggul P75 kestabilan lebih tinggi pada daerah hilir (FK 1,081) dibandingkan dengan daerah hulu tanggul.

\section{Kestabilan Lereng Tanggul P79}

Pada saat pengamatan lapangan pada Tanggul P79 terdapat temuan rekahan pada permukaan.
Ground Penetrating Radar (GPR) dilakukan untuk memantau distribusi rekahan tersebut. Pengukuran GPR dilakukan pada lintasan yang berarah tegak lurus (barat-timur) dari kelurusan rekahan, untuk menunjukkan kenampakan rekahan pada kondisi internal tangggul.

Pada penampang GPR dapat dilihat kenampakan rekahan pada permukaan tanggul terbentuk hingga kedalaman \pm 13 meter, ditunjukkan di Gambar 6. Rekahan tersebut menerus hingga inti tanggul. Akibat dari rekahan pada permukaan tanggul air yang mengalir dari permukaan yang dapat masuk ke inti tanggul melalui rekahan. Meningkatkan sumber resapan dari air menuju inti tanggul yang kemudian dapat mengakibatkan erosi internal pada tanggul.

Dari hasil analisis kestabilan lereng tanggul P79 keseluruhan tanggul masih berada pada kondisi rentan. Nilai dari kestabilan lereng sangat rendah yaitu kisaran 1,000 hingga 0,636. Hal ini dipengaruhi oleh ada rekahan pada tubuh tanggul yang kemudian mempengaruhi nilai kestabilan lereng. Walaupun belum adanya keruntuhan pada tanggul pada saat pengukuran geometri tanggul. Namun dari hasil analisis dapat dijadikan suatu catatan untuk ada perawatan lebih lanjut untuk mengurangi risiko keruntuhan pada Tanggul P79.

Pada penampang geolistrik menunjukkan anomaly yang diinterpretasikan sebagai erosi internal, yaitu kebasahan pada bagian inti tanggul. Hal tersebut semakin memperburuk kondisi tanggul, sehingga memerlukan penguatan tanggul untuk menghindari terjadinya kerutuhan pada tubuh tanggul.

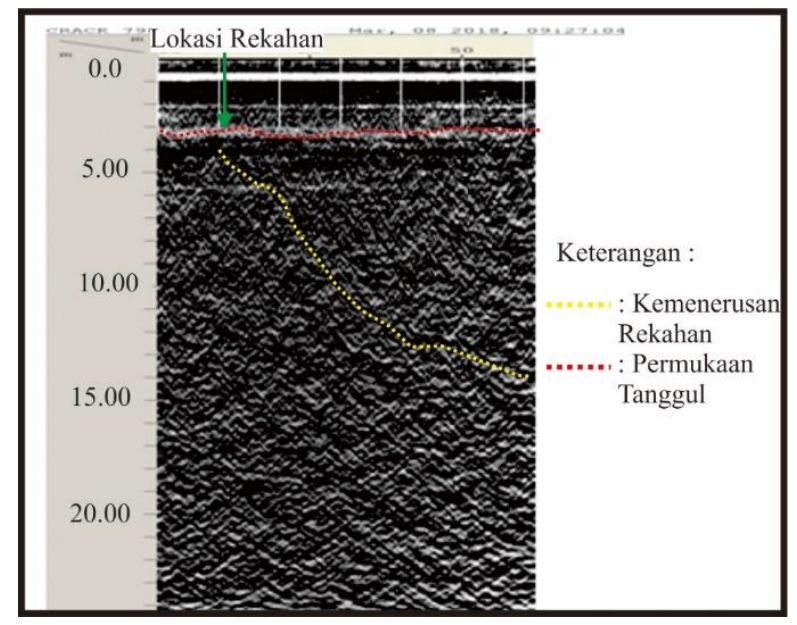

Gambar 6. Kenampakan rekahan dalam penampang GPR hasil cross section (BPLS, 2017). 


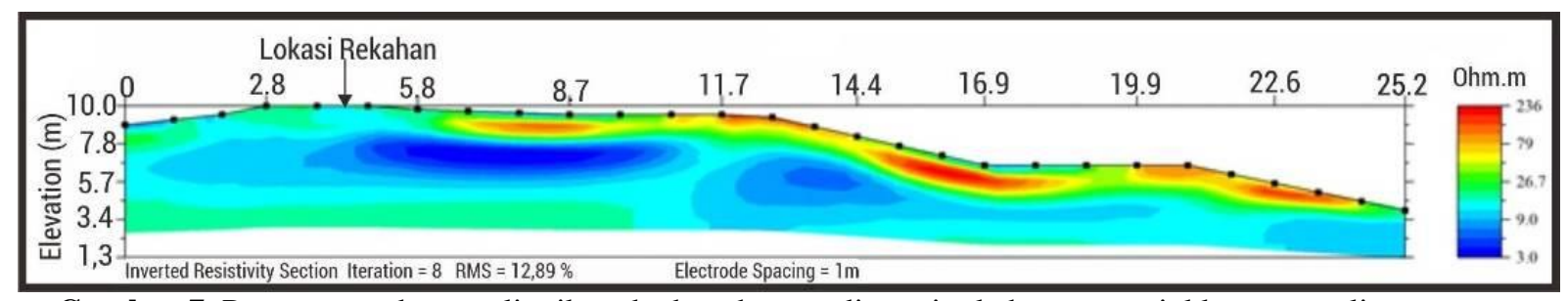

Gambar 7. Penampang data geolistrik pada daerah yang ditemui rekahan menunjukkan anomali penurunan resistivitas yang merupakan indikasi erosi internal.

\section{Rekomendasi}

Pada analisis kestabilan lereng yang dilakukan pada tubuh Tanggul Sidoarjo dengan beberapa kondisi tanggul yang berbeda memiliki kondisi nilai faktor keamanan (FK) yang mempunyai batas yang berbeda sesuai dengan kondisinya. Batas aman yang diambil merupakan batas aman berdasarkan dari Badan Standardisai Nasional 2016 (BSN 2016) yang merupakan batas nilai aman dari bendungan tipe urugan tipe homogen.

Dari hasil analisis tanggul P74 dan P75 merupakan tanggul yang masih dapat dikategorikan aman. Namun dalam kondisi surut tiba-tiba nilai dari faktor kestabilan lerang pada umumnya mengalami penurunan nilai faktor keamanan. Hal ini tentunya dapat mengakibatkan potensi kelongsoran. Pada tanggul P79 nilai keseluruhan dari tanggul memiliki nilai yang sangat rendah. Tanggul 79 merupakan tanggul yang jauh dari kata aman dengan nilai $\mathrm{FK}<1$. Hal ini merupakan sesuatu yang bahaya apabila tidak dilakukan penanggulangan.

Oleh sebab itu harus adanya peningkatan nilai keamanan dengan adanya rekayasa geoteknik, diharapkan dapat membentuk lereng yang mempunyai nilai faktor keamanan dengan besaran nilai yang stabil berdasarkan BSN 2016. Rekomendasi penanggulan yang disarankan dalam penelitian ini antara lain:

a. Pemadatan Tanah.

Pemadatan tanah adalah suatu proses untuk mengurangi pori-pori dari tanah secara mekanis. Pemadatan dibutuhkan untuk menaikan kekuatan tanah, memperkecil daya rembesan air, dan memperkecil pengaruh air terhadap tanah tersebut, terlebih pada tanggul P79 memiliki rekahan dan juga nilai kadar air yang cukup tinggi pada inti tanggul.

b. Membuat bronjong kawat pada bagian hulu tanggul.

Pembuatan penahan berupa bronjong kawat guna melindungi dan memperkuat lereng tubuh bendungan. Pemasangan bronjong kawat agar lebih efektif perlu dilakukan perhitungan secara detail seperti perhitungan volume bronjong, kekuatan bronjong dan sebagainya. Pemasangan kawat bronjong dilakukan pada tanggul P79 guna untuk menghidari kelongsoran pada tanggul P79.

c. Pelandaian lereng tubuh bendungan dan penutupan rekahan.

Pelandaian lereng tubuh bendungan sangat disarankan dilakukan pada lokasi penelitian yang bertujuan untuk mengubah geometri lereng dengan cara mengecilkan sudut lereng. Namun dalam melakukan metode ini juga perlu ditinjau dari ruang bebas yang tersedia di lokasi penelitian tersebut apakah bisa dilakukan atau tidak. Pelandaian dilakukan pada keseluruhan tanggul, sedangkan untuk penutup rekahan dilakukan pada P79.

d. Pembuataan drainase pada hilir bendungan. Pembuatan drainase bertujuan untuk menjaga kondisi hilir tanggul pada kondisi kering. Sehingga proses erosi pada daerah hilir tanggul tidak terjadi. Terlebih pada daerah hilir tanggul terdapat daerah genangan air merupakan daerah rawa.

\section{KESIMPULAN}

Berdasarkan hasil observasi, daerah tanggul Lumpur Sidoarjo tersusun dari endapan aluvium berupa kerakal-kerikil, pasir, lempung, dan lumpur dari endapan sungai dan endapan pantai.

Material tanggul memiliki berat volume tanah $19,19 \mathrm{kN} / \mathrm{m} 3$, kohesi $0,25 \mathrm{kN} / \mathrm{m} 2$, sudut geser dalam 31,5 $\phi^{0}$. Berdasarkan peta geologi teknik terbagi menjadi 3 satuan antar lain satuan tanah urugan dengan ukuran butir pasir - kerikil, satuan tanah asli berupa lempung dan pasir dengan berat volume tanah $17,45 \mathrm{kN} / \mathrm{m} 3$, kohesi $39 \mathrm{kN} / \mathrm{m} 2$, sudut geser dalam $0 \phi^{0}$, satuan Lumpur Lapindo memiliki nilai kohesi 9,46 $\mathrm{kN} / \mathrm{m} 2$, sudut geser dalam $28,53 \phi^{0}$. 
Penanggulangan untuk memperkuat kestabilan lereng tanggul P74 dan P75 dapat dilakukan pelandaian pada daerah hulu tanggul. Tanggul P79 dapat dilakukan pelandaian pada daerah hulu tanggul, penimbunan untuk menutup rekahan, pemadatan tanah, dan pemasangan bronjong pada bagian hilir tanggul.

\section{UCAPAN TERIMAKASIH}

Penulis mengucapkan terima kasih kepada Badan Penanggulangan Lumpur Sidoarjo yang telah mengeluarkan izin penelitian di tanggul Lumpur Sidoarjo.

\section{DAFTAR PUSTAKA}

Badan Standardisasi Nasional, 2016. Metode Analisis Stabilitas Lereng Static Bendungan Tipe Urugan. Badan Standardisasi Nasional: Jakarta.

Badan Penanggulangan Lumpur Sidoarjo, 2017. Laporan Akhir Kegiatan Pemantauan Bawah Permukaan Tahun 2017. Badan Penanggulangan Lumpur Sidoarjo: Surabaya.

Bishop, A.W, 1955. The Use of the Slip Circle in the Stability Analysis of Earth Slopes. Geotechnique, Vol. 5, no. 1, London.

Husein, A., Sungkono., Wijaya, A., dan Hadi, S, 2014, Subsurface Monitoring of P.79 - P.82 LUSI Embankment using GPR Method to Locate Subsidence and Possible Failure, Proceeding of 15th International Conference on Ground Penetrating Radar 2014, Brussels, hal 278-283.

ICOLD, 2003, World register of dams, Paris, International Commission on Large Dams (ICOLD).

Mazzini, A., Etiope, G., dan Svensen, H., 2012. A new hydrothermal scenario for the 2006 Lusi eruption, Indonesia, Insights from gas geochemistry. Earth and Planetary Science Letters, vol. 317318, no. 0, hal. 305-318.

Pusat Studi Gempa Nasional, 2017, Peta Sumber dan Bahaya Gempa Indonesia Tahun 2017, Bandung, Badan Penerbit Pekerjaan Umum.

Rajagukguk, O. C. P., Turangan, A., dan Monitja, S., 2014, Analisis Kestabilan
Lereng dengan Metode Bishop Studi Kasus: Kawasan Citraland. Jurnal Sipil Statik, 2(3), hal.140-147.

Robbins, F. W., 1946. The Story of Water Supply. Oxford University Press: London, U.K. 